\title{
ANALISIS PEMUNGUTAN RETRIBUSI PASAR GUNA MENINGKATKAN EFEKTIFITAS PENDAPATAN DAERAH KABUPATEN PAMEKASAN
}

\author{
Ria Rachmawati \\ RieaAries@gmail.com \\ Prodi Akuntansi, Fakultas Ekonomi, Universitas Madura
}

\begin{abstract}
ABSTRAK
Tujuan penelitian ini adalah untuk menganalisis aktivitas-aktivitas pemungutan retribusi pasar guna meningkatkan efektivitas yang diterapkan pada Dinas Perindustrian dan Perdagangan Kabupaten Pamekasan dan Peraturan Daerah Nomor 13 Tahun 2012 tentang Retribusi Pasar. Jenis penelitian menggunakan deskriptif kuantitatif. Jenis data menggunakan data kuantitatif. Sumber data menggunakan data sekunder. Teknik pengumpulan data menggunakan teknik dokumentasi yang berupa laporan pendapatan asli daerah dan tahap-tahap analisis data yang digunakan dengan cara mengindetifikasi aktivitas-aktivitas pemungutan retribusi pasar, analisis efektifitas, analisis pertumbuhan dan analisis trend. Hasil penelitian menunjukkan bahwa aktivitas pemungutan retribusi pada Dinas Perindustrian dan Perdagangan Kabupaten Pamekasan sesuai dengan Keputusan Daerah Kabupaten Pamekasan Nomor 13 Tahun 2012 tentang Retribusi Pasar, sehingga peneliti menganggap bahwa aktivitas-aktivitas pemungutan Rertibusi Pasar pada Dinas Perindustrian dan Perdagangan Kabupaten Pamekasan sudah efektif. Berdasarkan perhitungan analisis efektifitas dinas perindustrian sudah efektif. Pertumbuhan penerimaan retribusi pasar mengalami penurunan yang cukup signifikan setiap tahunnya. Sedangkan rata-rata persentase pertumbuhan selama 3 tahun menunjukkan bahwa setiap tahunnya Dinas Perindustrian dan Perdagangan belum maksimal untuk pemungutan retribusi pasar sehingga tingkat pertumbuhannya belum terpenuhi.
\end{abstract}

Kata Kunci : Efektifitas, Retribusi Pasar, Laporan Pendapatan Asli Daerah.

\begin{abstract}
:
The purpose of this study was to analyze the activities of collecting market levies in order to increase the effectiveness of those applied to the Pamekasan Regency Industry and Trade Office and Regional Regulation No. 13 of 2012 concerning Market Levies. This type of research uses descriptive quantitative. This type of data uses quantitative data. The data source uses secondary data. The data collection technique uses documentation techniques in the form of local revenue reports and the stages of data analysis used by identifying market retribution collection activities, effectiveness analysis, growth analysis and trend analysis. The results showed that the activity of
\end{abstract}


collecting retribution at the Department of Industry and Trade of Pamekasan Regency was in accordance with the Regional Decree of Pamekasan Regency Number 13 of 2012 concerning Market Retribution, so that the researchers considered that the activities of collecting Market Retribution at the Department of Industry and Trade of Pamekasan Regency had been effective. Based on the calculation of the effectiveness analysis of the industrial office, it has been effective. The growth of market retribution revenue has decreased significantly every year. Meanwhile, the average percentage growth for 3 years shows that every year the Department of Industry and Trade has not been maximized for collecting market levies so that the growth rate has not been met.

Keywords : Effectiveness, Market Levy, Local Revenue Report.

\section{PENDAHULUAN}

Pada era otonomi daerah seperti sekarang ini, fungsi dari peranan pajak daerah retribusi daerah sebagai salah satu sumber penerimaan negara yang sangat penting. Sejalan dengan otonomi daerah masalah penimbangan keuangan pusat dan daerah merupakan salah satu elemen penting untuk di lakukan dalam kaitannya dengan otonomi daerah ${ }^{1}$.

Sumber penerimaan daerah Kabupaten Pamekasan yang lebih memungkinkan untuk dikembang]kan saat ini adalah penerimaan retribusi. Retribusi itu merupakan harga dan suatu pelayanan langsung dari Pemerintah Daerah yang digunakan untuk menyediakan tempat pasar yang strategis. Pemerintah Daerah memungut retribusi tersebut kepada setiap pengguna sarana pasar. Sedangkan dari pihak masyarakat ]langsung dapat merasakan timbal balik jasa yang di berikan oleh Pemerintah Daerah.

Beberapa alasan peneliti mengemukakan mengenai retribusi pasar yang di teliti tercakup dalam retribusi daerah adalah terdapat dua golongan retribusi pasar dan retribusi pasar grosir dan toko yang sistem pemungutannya sama tetapi di bedakan dalam retibusi daerah yang nantinya akan dimasukkan ke dalam satu golongan yaitu retribusi pasar. Bila di lihat dari pendapatan pasar grosir dan pertokoan sangat material bagi retribusi pasar. Selain itu ruang lingkup retribusi pasar yang dipilih spesifik sehingga diketahui besarnya kontribusi pasar terhadap Pendapatan Asli Daerah dibandingkan dengan Retribusi Daerah lainnya atau Pendapatan Asli Daerah lainnya.

Berkaitan dengan hal diatas, peneliti menganggap bahwa sistem pemungutan retribusi pasar mempunyai perananan penting pada Dinas Perindustrian dan

1 Devas, Nick, dik.(1989). Keuangan Pemerintah Daerah di Indonesia, UI-Press, Jakarta. 
Perdagangan Kabupaten Pemekasan. Dimana sistem pemungutam retribusi pasar tersebut merupakan alat yang digunakan untuk mengukur dan mengorganisir serta mengkoordinasi seluruh kegiatan. B]aik kegiatan yang menyangkut transaksi maupun kegiatan dari seluruh personil untuk menjalankan tugas sesuai dengan fungsinya.

Dari uraian di atas dapat di simpulkan bahwa sistem pemungutan retribusi pasar penting bagi organisasi pemerintahan. Oleh karena itu menjadi tanggung jawab Pemerintah Daerah untuk mengawasi terus-menerus dan mengevaluasi kembali pemungutan retribusi daerah. Dengan latar belakang permasalahan di atas, maka dirumuskan masalah "Bagaimana pemungutan retribusi pasar yang diterapkan oleh dinas perindustrian dan perdagangan kabupaten pamekasan dapat lebih efektif?".

\section{KAJIAN PUSTAKA}

\section{Pengertian Retribusi Daerah}

Retribusi merupakan sumber pendapatan daerah yang dipungut berdasarkan perundang-undangan yang berlaku. Menurut ${ }^{2}$ Retribusi daerah adalah pungutan daerah sebagai pembayaran atas jasa atau pemberian izin tertentu yang khusus disediakan dan/atau diberikan oleh pemerintah daerah untuk kepentingan pribadi atau badan. Adapun pengertian retribusi lain menurut ${ }^{3}$ iuran kepada pemerintah yang dapat dipaksakan dan jasa balik secara langsung dapat ditunjuk. Paksaan disini bersifat ekonomis karena siapa saja yang tidak merasakan jasa balik dari pemerintah, tidak dikenakan iuran.

\section{Pengertian Retribusi Pasar}

${ }^{4}$ Retribusi pasar mempunyai pengertian pungutan yang dikenakan kepada pedagang oleh pemerintah daerah sebagai pembayaran pemakaian tempat-tempat yang disediakan pemerintah daerah sebagai pasar. Menurut pemerinah daerah Kabupaten Pamekasan Nomor 5 Tahun 2000 pasal 1 "pasar adalah suatu tempat dengan batas tertentu yang disediakan untuk melakukan usaha kegiatan perdagangan dikuasai dan dikelola oleh pemerintah daerah".

\section{Objek Retribusi Pasar}

5Obyek retribusi pasar adalah pelayanan penyediaan fasilitas pasar

2 Suparmoko, M. (2002). Ekonomi Publik, Untuk Keuangan danPembangunan Daerah. Andi. Yogyakarta 3 Munawir, S.(2000). Analisa Laporan Keuangan. Yogyakarta: Liberty.

4 Resmi,Siti. (2005). Perpajakan Teori dan Kasus. Edisi ke empat. Salemba Empat. Jakarta.

5 Ibid 
tradisional/sederhana yang berupakios/bedak/pelataran/los yang dikelola pemerintah daerah dan khusus disediakan untuk pedagang. Tidaktermasuk obyek retribusi pasar adalah pelayanan fasilitas pasar yang dimiliki dan atau dikelola oleh pihak swasta maupun perusahaan daerah.

\section{Subyek Retribusi Pasar}

Subyek retribusi pasar adalah orang pribadi atau badan yang menggunakan/memanfaatkan/menikmatijasa pelayanan penyediaan fasilitas pasar yang dimaksud dengan badan adalah suatu bentuk usaha yang meliputiperseroan terbatas, perseroan komanditer, perseroan lainnya, badan usaha milik negara atau daerah dengan namadan bentuk apapun, persekutuan, perkumpulan, firma, kongsi, koperasi, yayasan atau organisasi yang sejenis,lembaga, dana pensiun, bentuk usaha tetap serta bentuk usaha lainnya.

\section{Pendapatan Daerah}

Menurut ${ }^{6}$ pengertian pendapatan daerah adalah peningkatan aktiva tetap atau penurunan hutang yang berasal dari berbagai kegiatan periode tahun angga]ran bersangkutan.

7Berdasarkan Peraturan Pemerintah Republik Indonesia Nomor 105 Tahun 2000 tentang pengolahan pertanggung jawaban keuangan daerah, pengertian pendapatan daerah yaitu semua penerimaan kas daerah dalam periode tahun anggaran tertentu yang menjadi ]hak daerah. Berdasarkan pasal 64 ayat (2) Undang-Undang nomor 5 Tahun 1974 tentang pokok-pokok pemerintah daerah, APBN dapat didefinisikan yaitu rencana operasional keuangan pemerintah daerah, dimana disatu pihak menggambarkan perkiraan pengeluaran setinggi tingginya guna membiayai kegiatankegiatan dan proyek-proyek derah dalam tahun anggaran tertentu dan pihak lain menggambarkan perkiraan penerimaan dan sumber-sumber derah guna menutupi pengeluaran tersebut.

Adapun pengertian pendapatan daerah yang lain yaitu usaha daerah untuk daerah yang diatur dalam peraturan daerah dan dugunakan untuk membiayai pengeluaran daerah sebagaimana ditetapkan dalam anggaran pendapatan dan belanja 
daerah.

\section{Sumber-sumber Pendapatan Asli Daerah}

8Sebagaimana diatur dalam pasal 5 Undang-undang Nomor 33 tahun 2004, sumber-sumber Pendapatan Asli Daerah (PAD) terdiri dari:

1. Pajak Daerah

Pajak daerah mempunyai pengertian negara yang diserahkan kepada daerah untuk dipungut berdasarkan peraturan Undang-undang yang digunakan guna membiayai pengeluaran daerah.

2. Retribusi Daerah

Retribusi daerah adalah pungutan daerah sebagai pembayaran atas pemakaian jasa atau karena mendapatkan jasa pekerjaan, usaha atau milik daerah untuk kepentingan umum, atau karena jasa yang diberikan oleh hak langsung atau tidak langsung.

3. Hasil Pengelolaan kekayaan yang terpisahkan.

Hasil pengelolaan kekayaan daerah yang dipisahkan, perusahaan daerah mempunyai pengertian suatu badan usaha yang dibentuk oleh daerah untuk memperkembangkan perekonomian daerah dan untuk menambah penghasilan daerah.

4. Lain-lain Pendapatan asli daerah yang sah

Sumber pendapatan ini tidak tergolong pada sumber pendapatan murni daerah ataupun pendapatan yang berasal dari pembeian pemerintah.

Sedangkan pembiayaan bersumber dari :

a. Sisa lebih perhitungan anggaran Daerah;

b. Penerimaan Pinjaman Daerah;

c. Dana Cadangan Daerah dan;

d. Hasil Penjualan Kekayaan Daerah yang dipisahkan.

\section{Rasio Efektifitas}

${ }^{9}$ efektifitas merupakan suatu ukuran yang memberikan gambaran seberapa jauhtarget dapat dicapai. Pengertian efektifitas ini lebih berorientasi kepada keluaran sedangkan masalahpenggunaan masukan kurang menjadi perhatian utama. Apabila efisiensi dikaitkan dengan efektifitas makawalaupun terjadi peningakatan efektifitas

8 Setiawan \& Basri Musri. (2006). perpajakan umum, Edisi 1, PT. Raja Grafindo Persada. Jakarta.

9 Abdul Halim. (2004). Akuntansi Keuangan Daerah, Penerbit Salemba Empat, Jakarta 
belum tentu efisiensi meningkat.

10Mengukur efektivitas organisasi bukanlah suatu hal yang sangat sederhana, karena efektivitas dapat dikaji dari berbagai sudut pandang dan tergantung pada siapa yang menilai serta menginterpretasikannya. Bila dipandang dari sudut produktivitas, maka seorang manajer produksi memberikan pemahamanbahwa efektivitas berarti kualitas dan kuantitas (output) barang dan jasa. ${ }^{11}$ Tingkat efektivitas juga dapat diukur dengan membandingkan antara rencana yang telah ditentukan dengan hasil nyata yang telah diwujudkan. Namun, jika usaha atau hasil pekerjaan dan tindakan yang dilakukan tidak tepat sehingga menyebabkan tu]juan tidak tercapai atau sasaran yang diharapkan, maka hal itu dikatakan tidak efektif.

\section{METODOLOGI}

\section{Lokasi Penelitian}

Penelitian ini dilakukan pada Dinas Perindustrian dan Perdagangan Kabupaten Pamekasan, dengan alamat Jl. Raya Pamekasan-Sumenep No.201, Serkeser, Buddagan, Pademawu, Kabupaten Pamekasan, Jawa Timur.

\section{Jenis Penelitian}

Jenis penelitian ini adalah jenis penelitian deskriptif kuantitatif. Menurut ${ }^{12}$ penelitian deskriptif adalah aliran yang bertujuan untuk mendeskripsikan suatu keadaan atau obyek yang menjadi perhatian dalam kegiatan penelitian secara sistematis. Penelitian kuantitatif disebut juga pendekatan traditional, positivism, experimental, dan empiricits. Penelitian kuantitatif menekankan pada pengujian teoriteori dan atau hipotesis melalui pengukuran variabel-variabel penelitian dalam angka (quantitative) dan melakukan analisis data dengan prosedur statistik dan atau pemodelan matematis.

\section{Jenis Data}

Jenis data dalam penelitian ini adalah data kuantitatif. Data kuantitatif menurut ${ }^{13}$ adalah data yang berupa angka atau bilangan. Dalam penelitian ini data kuantitatif yang berupa Realisasi Pendapatan Asli Daerah yang dimiliki oleh Dinas

\footnotetext{
10 Syamsudin, dan Primayuta, Ceky. (2009). Rasio Keuangan dan Prediksi Perubahan Laba Perusahaan Manufaktur. Jurnal Manajemen dan Bisnis. Vol 13, No. 1: 61-69

11 Wibowo, Agus, Hendra, dan Pujiati, Diyah. (2011). Analisis Rasio Keuangan dalam Memprediksi Perubahan Laba Pada Perusahaan Real Estate dan Property di Bursa Efek Indonesia (BEI) dan Singapura (SAG). STIE Perbanas Surabaya. Vol 1. No.2: 155-178,

12 Bahri, Syaiful. (2018). Metodelogi Penelitian Bisnis. Yogyakarta. Andi offset.

13 Ibid
} 
Perindustrian dan Perdagangan Kabupaten Pamekasan.

\section{Sumber Data}

Sumber data yang digunakan dalam penelitian ini adalah data sekunder. Menurut ${ }^{14}$ data sekunder adalah data yang diperoleh secara tidak langsung dan melalui media perantara, berasal dari sumber-sumber yang telah ada atau data sudah tersedia dan dikumpulkan oleh pihak lain yang berupa bukti, catatan atau laporan historis. Yang meliputi struktur organisasi Dinas Perindustrian dan Perdagangan Kabupaten Pamekasan dan Realisasi Pendapatan Asli Daerah Kabupaten Pamekasan.

\section{Teknik Pengumpulan Data}

Menurut ${ }^{15}$ metode pengumpulan data dilakukan untuk memperoleh informasi yang dibutuhkan dalam rangka mencapai tujuan penelitian. Untuk memperoleh data dalam penelitian ini maka peneliti menggunakan teknik pengumpulan data yang berupa Realisasi Pendapatan Asli Daerah.

\section{Dokumentasi}

Dalam penelitian ini, dokumentasi yang diperlukan berupa Realisasi Pendapatan Asli Daerah Kabupaten Pamekasan.

\section{Definisi Operasional Variabel}

Menurut ${ }^{16}$ definisi operasional merupakan operasionalisasi konstruk dengan tujuan untuk memberikan nilai pada konstruk tersebut. Konstruk adalah elemen dari teori dan dapat berupa sebuah pandangan atau pendapat yang biasanya ditemukan untuk sebuah penelitian atau pembentukan teori. Maka definisi operasional merupakan penjelasan tentang variabel-variabel dengan cara memberi arti atau penjelasan operasionalisasi variabel oleh peneliti. Definisi operasional dalam penelitian ini adalah:

a. Realisasi Pendapatan Asli Daerah adalah suatu bentuk pertanggungjawaban daerah yang mencakup keseluruhan penerimaan daerah baik berupa uang atau perhitungan material lainnya dari sumber-sumber yang jelas untuk jangka waktu tertentu berdas]arkan peraturan perundang-undangan yang berlaku untuk membiayai kebutuhan-kebutuhan daerah dalam rangka memenuhi kewajibannya untuk mengatur dan mengurus rumah tangganya sendiri. 
b. Rasio Efektifitas bertujuan untuk mengukur rasio keberhasilan, semakin besar maka semakin efektif standar minimal rasio keberhasilan adalah $100 \%$ atau 1 (satu) dimana realisasi dengan target telah ditentukan. Sedangkan rasio dibawah standar minimal keberhasilan dapat dikatakan tidak efektif.

c. Rasio pertumbuhan merupakan rasio yang bertujuan untuk mengukur kemampuan perusahaan dalam mempertahankan posisi ekonominya dari tahun ke tahun.

d. Efektifitas Pendapatan Asli Daerah adalah suatu alat untuk mengukur tingkat keberhasilan daerah dimana semakin besar pendapatan asli daerah tersebut maka semakin efektif dan sebaliknya, semakin kecil pendapatan asli daerah tersebut maka dapat dikatakan tidak efektif.

\section{Teknik Analisa Data}

Mengumpulkan data laporan Realisasi Pendapatan Asli Daerah Kabupaten Pamekasan.

\section{HASIL DAN PEMBAHASAN}

\section{Analisis Efektifitas}

Tabel 1

Target Dan Realisasi Retribusi Pasar

Kabupaten Pamekasan

Tahun 2017-2019

\begin{tabular}{ccccc}
\hline Tahun & Target & \multicolumn{2}{c}{ Realisasi } & Efektifitas (\%) \\
\hline 2017 & Rp 363,732,000 & Rp & $419,840,500$ & $115.43 \%$ \\
2018 & $R p ~ 357,260,000$ & $R p$ & $352,761,750$ & $98.74 \%$ \\
2019 & $R p ~ 355,260,000$ & $R p$ & $361,441,500$ & $101.74 \%$ \\
\hline
\end{tabular}

Sumber: Data diolah peneliti: 2021

Pada tahun 2018 target yang ditetapkan sebesar Rp 357,260,000 sedangkan realisasi penerimaan retribusi pasar sebesar Rp 352,761,750 yang tidak mencapai target yang ditetapkan. Hal ini disebabkan karena kondisi naik turunnya penerimaan retribusi pasar bergantung pada banyaknya para pedagang dan terkadang hari pasaran bersamaan dengan hari libur nasional. Tingkat efektifitas tersebut dikarenakan adanya kedisiplinan dan pengawasan petugas dilapangan dan kesadaran para pedagang didalam pasar untuk membayar retribusi yang telah ditetapkan oleh pemerintah daerah kabupaten pamekasan. 


\section{Analisis Pertumbuhan}

Tabel 2

Perkembangan Realisasi Retribusi

PasarKabupaten Pamekasan

Tahun 2017-2019

\begin{tabular}{clcc}
\hline Tahun & \multicolumn{2}{l}{ Realisasi Retribusi Pasar } & Pertumbuhan $(\%)$ \\
\hline 2017 & $\mathrm{Rp}$ & $419,840,500$ & $-24.69 \%$ \\
2018 & $\mathrm{Rp}$ & $352,761,750$ & $-15.98 \%$ \\
2019 & $\mathrm{Rp}$ & $361,441,500$ & $2.46 \%$ \\
\hline
\end{tabular}

Sumber: Data diolah peneliti: 2021

Pertumbuhan penerimaan retribusi pasar mengalami penurunan yang cukup signifikan setiap tahunnya dan disebabkan oleh potensi pasar yang menurun akibat dari musim panen yang gagal yang sangat berpengaruh besar pada aktivitas pasar dan juga disebabkan oleh belum optimalnya Dinas Perindustrian Dan Perdagangan mengupayakan pemungutan retribusi pasar sehinggga tingkat pertumbuhannya belum terpenuhi.

\section{KESIMPULAN DAN SARAN}

\section{Kesimpulan}

Bila dilihat dari pelaksanaan sistem pemungutan retribusi pasar sudah efektif. Hal ini disebabkan karena kesadaran dari para pedagang sangat tinggi dalam menggunakan fasilitas yang diberikan oleh pemerintah.

Tingkat pertumbuhan penerimaan retribusi pasar selama kurun waktu 3 tahun di Kabupaten Pamekasan mengalami penurunan yang cukup signifikan.. Hal ini disebabkan oleh potensi pasar yang menurun akibat dari musim panen yang gagal yang sangat berpengaruh besar pada aktivitas pasar dan juga belum optimalnya petugas lapangan untuk mengupayakan pemungutan retribusi pasar sehingga tingkat pertumbuhannya belum terpenuhi.

\section{Saran}

a. Bagi Dinas Perindustrian dan Perdagangan

Dalam menentukan target pendapatan daerah atas retribusi pasar sebaiknya 
didasarkan pada faktor-faktor yang mempengaruhi penerimaan Retribusi Pasar yaitu subjek dan objek pasar.

b. Bagi Peneliti Selanjutnya

Peneliti menyarankan untuk peneliti selanjutnya agar menambah variabel penelitian, seperti Retribusi Pelayanan Pasar dan Retribusi Pemakaian Kekayaan Daerah. Peneliti juga menyarankan untuk menambah tahun penelitian misalnya lebih dari 3 tahun agar peneliti selanjutnya dapat mengetahui tingkat keefektifannya.

\section{DAFTAR PUSTAKA}

Suparmoko, M. (2002). Ekonomi Publik, Untuk Keuangan danPembangunan Daerah. Andi. Yogyakarta

Munawir, S.(2000). Analisa Laporan Keuangan. Yogyakarta: Liberty.

Abdul Halim. (2004). Akuntansi Keuangan Daerah, Penerbit Salemba Empat, Jakarta

Bahri, Syaiful. (2018). Metodelogi Penelitian Bisnis. Yogyakarta. Andi offset.

Devas, Nick, dik.(1989). Keuangan Pemerintah Daerah di Indonesia, UI-Press, Jakarta.

Resmi,Siti. (2005). Perpajakan Teori dan Kasus. Edisi ke empat. Salemba Empat. Jakarta.

Setiawan \& Basri Musri. (2006). perpajakan umum, Edisi 1, PT. Raja Grafindo Persada. Jakarta.

Syamsudin, dan Primayuta, Ceky. (2009). Rasio Keuangan dan Prediksi Perubahan Laba Perusahaan Manufaktur. Jurnal Manajemen dan Bisnis. Vol 13, No. 1: 61-69

Wibowo, Agus, Hendra, dan Pujiati, Diyah. (2011). Analisis Rasio Keuangan dalam Memprediksi Perubahan Laba Pada Perusahaan Real Estate dan Property di Bursa Efek Indonesia (BEI) dan Singapura (SAG). STIE Perbanas Surabaya. Vol 1. No.2: 155-178, 